\title{
The Association between Parathyroid Hormone (PTH) Level and Hemoglobin and Hematocrit Level in Chronic Kidney Disease (CKD) Patients with Regular Hemodialysis
}

\author{
Hendri Wahyudi Pinem ${ }^{1}$, Alwi Thamrin Nasution², Bayu Rusfandi Nasution² \\ ${ }^{1}$ Department of Internal Medicine, Faculty of Medicine, Universitas Sumatera Utara, Medan, Indonesia \\ ${ }^{2}$ Division of Nephrology, Department of Internal Medicine, Faculty of Medicine, Universitas Sumatera Utara, \\ Medan, Indonesia
}

Corresponding Author: Hendri Wahyudi Pinem

\begin{abstract}
Introduction: Chronic Kidney Disease (CKD) is a pathophysiological process with various etiology that causes a progressive decline in kidney function and ends in kidney failure. [1] CKD is a health problem that occurs in the community and has covered globally. The 2010 Global Burden of Disease stated that CKD was the 27th leading cause of death in the world in 1990. This has increased to 18th in 2010. Parathyroid hormone is a potential factor in the incidence of anemia in CKD patients. In CKD patients, there is an increase in levels of parathyroid hormone which is a uremic toxin that inhibits erythropoietin by increasing fibrosis in the bone marrow (myelofibrosis). The role of PTH in cases of renal anemia has been extensively investigated by various clinical observational studies. This study aimed to determine the association between parathyroid hormone (PTH) levels and hemoglobin and hematocrit levels in chronic kidney disease (CKD) patients with regular hemodialysis in Haji Adam Malik Central General Hospital.

Methods: This is an analytical study with a cross-sectional design. A total of 45 study subjects met the inclusion criteria and exclusion criteria, underwent history taking, physical examination, anthropometry, and laboratory examination to measure parathyroid hormone, hemoglobin, hematocrit, and albumin levels. Data analysis was performed using SPSS.
\end{abstract}

Results: The measured PTH level had a minimum value of $113 \mathrm{pg} / \mathrm{ml}$ and a maximum of
$595 \mathrm{pg} / \mathrm{ml}$ with an average of 431.4. The minimum hemoglobin value is $6.3 \mathrm{~g} / \mathrm{dl}$ and a maximum of $11.5 \mathrm{~g} / \mathrm{dl}$ with an average of 7.9 , while for the hematocrit the minimum value is $19 \%$ and the maximum is $35 \%$ and the average is 24.7. The Mann-Whitney U test showed that there is a significant relationship between PTH levels and hemoglobin, indicated by a significant $\mathrm{p}$ value of 0.001 ( $\mathrm{p}$ value $<0.05$ ). A significant relationship was also found between PTH levels and hematocrit ( $p$ value $=0.039$ ).

Conclusion: Parathyroid hormone has a statistically significant relationship with haemoglobin and haematocrit levels in CKD patients with regular hemodialysis.

Keywords: Chronic kidney disease; haemoglobin; haematocrit; parathyroid hormone; anemia; hemodialysis

\section{INTRODUCTION}

Chronic Kidney Disease (CKD) is a pathophysiological process with various etiology that causes a progressive decline in kidney function and ends in kidney failure. [1] CKD is a health problem that occurs in the community and has covered globally. The 2010 Global Burden of Disease stated that CKD was the 27th leading cause of death in the world in 1990. This has increased to 18th in 2010. [2]

Renal hyperparathyroidism (rHPT) is one of the most common complications of CKD. This condition is characterized by 
disturbances in the homeostasis of calcium, phosphorus, and vitamin D. An increase in parathyroid hormone levels tends to occur when the glomerular filtration rate (GFR) decreases, which is less than 60 $\mathrm{mL} / \mathrm{min} / 1.73 \mathrm{~m}^{2}$. [3]

Parathyroid hormone $(\mathrm{PTH})$ is a potential factor in the incidence of anemia in CKD patients. In CKD patients, there is an increase in levels of parathyroid hormone which is a uremic toxin that inhibits erythropoietin by increasing fibrosis in the bone marrow (myelofibrosis). Increased levels of parathyroid hormone will also increase the fragility of red blood cells which triggers a shortening of erythrocyte lifespan and inhibits the proliferation of erythroid precursors. Based on in vitro studies, low PTH levels are known to trigger heme synthesis, but high levels cause the opposite, inhibiting heme synthesis. [4,5]

The role of PTH in cases of renal anemia has been extensively investigated by various clinical observational studies. One of these is the Kalantar Zadech study which analyzed a national database of a large dialysis organization and showed that PTH levels were indirectly associated with a decreased response to erythropoiesisstimulating agents (ESA). Gaweda et al. reported similar results in which there was a significant relationship between increased levels of parathyroid hormone and decreased erythropoetic response. [5] This study aimed to determine the association between parathyroid hormone (PTH) levels and hemoglobin and hematocrit levels in chronic kidney disease (CKD) patients with regular hemodialysis in Haji Adam Malik Central General Hospital.

\section{MATERIALS \& METHODS}

This study is an analytical study with a cross-sectional design. The study was conducted at the Haji Adam Malik Central General Hospital (RSUP) Medan after obtaining approval from the Health Research Ethics Commission of USU Medical Faculty / H. Adam Malik Hospital Medan starting from January 2021. A total of 45 study subjects met the inclusion criteria and exclusion criteria. The study inclusion criteria were as follows: CKD patients undergoing regular hemodialysis $(\geq$ 3 months), at least 18 years old, and with informed consent to participate in the study. Data were obtained from medical record data including patient identity, duration of hemodialysis, and history of CKD. Subjects underwent history taking, physical examination, anthropometry, and laboratory examination to measure parathyroid hormone, hemoglobin, hematocrit, and albumin levels.

\section{Statistical Analysis}

Data analysis was performed using the Statistical Package for the Social Sciences (SPSS) 24.0 software. Numerical variables is presented in the form of mean \pm standard deviation if the data is normally distributed, and in median (minimum value - maximum value) if the data is not normally distributed. Categorical variables were presented as percentages. Independent $t$ test is carried out for the calculation of the quantile of PTH levels if it meets the requirements or Mann-Whitney $U$ test if it does not meet the requirements.

\section{RESULT}

This study included 45 research subjects of CKD patients at the Haji Adam Malik Central General Hospital Medan in 2021 who had met the inclusion and exclusion criteria. The average age of the research subjects was 51,8 years, the majority of the research subjects were male (28 people [62.2\%]) and women (17 people [37.8\%]) (Table 1).

Table 1. Sex Distribution

\begin{tabular}{|c|c|c|c|}
\hline \multicolumn{2}{|l|}{ Sex } & Total & $\%$ \\
\hline & Men & 28 & 62,2 \\
\hline & Women & 17 & 37,8 \\
\hline & Total & 45 & 100.0 \\
\hline
\end{tabular}

The measured PTH level had a minimum value of $113 \mathrm{pg} / \mathrm{ml}$ and a maximum of $595 \mathrm{pg} / \mathrm{ml}$ with an average of 431.4. The minimum hemoglobin value is $6.3 \mathrm{~g} / \mathrm{dl}$ and a maximum of $11.5 \mathrm{~g} / \mathrm{dl}$ with an 
Hendri Wahyudi Pinem et.al. The association between parathyroid hormone (PTH) level and hemoglobin and hematocrit level in chronic kidney disease (CKD) patients with regular hemodialysis.

average of 7.9, while for the hematocrit the minimum value is $19 \%$ and the maximum is $35 \%$ and the average is 24.7 . The measured albumin value obtained a minimum value of
$2.8 \mathrm{~g} / \mathrm{dl}$ and a maximum of $4.1 \mathrm{~g} / \mathrm{dl}$ with an average of 3.4. The characteristics of the subjects are presented in (Table 2).

Tabel 2. Subject Characteristics

\begin{tabular}{|l|l|l|l|l|l|}
\hline & N & Minimum & Maximum & Mean & Std. Deviation \\
\hline Age & 45 & $24 \mathrm{tahun}$ & $77 \mathrm{tahun}$ & 51,8 & 12,75 \\
\hline $\mathrm{PTH}$ & 45 & $113 \mathrm{pg} / \mathrm{ml}$ & $595 \mathrm{pg} / \mathrm{ml}$ & 431,4 & 120,5 \\
\hline $\mathrm{Hb}$ & 45 & $6,3 \mathrm{gr} / \mathrm{dl}$ & $11,5 \mathrm{gr} / \mathrm{dl}$ & 7,9 & 1,32 \\
\hline $\mathrm{Ht}$ & 45 & $19 \%$ & $35 \%$ & 24,7 & 4,01 \\
\hline Albumin & 45 & $2,8 \mathrm{gr} / \mathrm{dl}$ & $4,1 \mathrm{gr} / \mathrm{dl}$ & 3,4 & 0,36 \\
\hline URR & 45 & 36 & 97 & 66,9 & 11,4 \\
\hline HD duration & 45 & $3 \mathrm{bulan}$ & $10 \mathrm{bulan}$ & 5,5 & 1,8 \\
\hline Iron serum & 45 & $43 \mathrm{ug} / \mathrm{dl}$ & $132 \mathrm{ug} / \mathrm{dl}$ & 76,9 & 19 \\
\hline TIBC & 45 & $81 \mathrm{ug} / \mathrm{dl}$ & $331 \mathrm{ug} / \mathrm{dl}$ & 159,5 & 59,7 \\
\hline Ferritin & 45 & $115 \mathrm{ug} / \mathrm{dl}$ & $716 \mathrm{ug} / \mathrm{dl}$ & 367,2 & 167,1 \\
\hline Calcium & 45 & $5,4 \mathrm{mg} / \mathrm{dl}$ & $9,6 \mathrm{mg} / \mathrm{dl}$ & 8,1 & 0,72 \\
\hline Phosphate & 45 & $3,5 \mathrm{mg} / \mathrm{dl}$ & $8,8 \mathrm{mg} / \mathrm{dl}$ & 6 & 1,43 \\
\hline Magnesium & 45 & $1,6 \mathrm{mg} / \mathrm{dl}$ & $2,6 \mathrm{mg} / \mathrm{dl}$ & 2,1 & 0,27 \\
\hline
\end{tabular}

Based on the use of EPO, rom a total of 45 patients, 37 patients undergoing hemodialysis received alpha EPO type, and 8 patients received beta EPO type. Each patient received one dose of EPO per week. (Table 3)

Table 3. EPO Type Distribution

\begin{tabular}{|c|c|c|}
\hline EPO Type & Total & $\%$ \\
\hline Alpha & 37 & 82,2 \\
\hline Beta & 8 & 17,8 \\
\hline
\end{tabular}

Based on the use of phosphate binders, from a total of 45 patient, 6 patients undergoing hemodialysis received cavit D3 and 39 samples received ostriol. (Table 4) All 45 patients received the same type of iron supplementation. (Table 5)

Table 4. Phosphate Binder Distribution

\begin{tabular}{|l|l|l|}
\hline Phosphate Binder & Total & \% \\
\hline Cavit D3 & 6 & 13,3 \\
\hline Ostriol & 39 & 86,7 \\
\hline
\end{tabular}

Table 5. Iron Supplementation Distribution Iron Supplement Ferro Sulphate Tota 45 $\%$ 100

Table 6. The Relationship Between Parathyroid Hormone and Other Variables

\begin{tabular}{|l|l|}
\hline Variable & p value \\
\hline PTH with Calcium & 0.993 \\
PTH with Magnesium & 0,809 \\
PTH with Phosphate & 0,293 \\
PTH with Calcium Phosphate & 0,043 \\
\hline
\end{tabular}

In this study, no relationship was found between parathyroid hormone and calcium, magnesium, and phosphate levels. However, there is a significant relationship between parathyroid hormone and calcium phosphate values with a $\mathrm{p}$ value of 0.043 ( $\mathrm{p}$ value < 0.05). (Table 6)

By using independent $t$ test, no relationship was found between ferritin and hemoglobin levels ( $\mathrm{p}$ value $=0.346$ ). (Table 7) The Mann-Whitney U test showed that there is a significant relationship between PTH levels and hemoglobin, indicated by a significant $p$ value of 0.001 ( $p$ value $<0.05$ ). (Table 8) A significant relationship was also found between PTH levels and hematocrit $(p$ value $=0.039)$. $($ Table 9)

Table 7. The Relationship Between Ferritin and Hemoglobin Levels

\begin{tabular}{|l|l|l|}
\hline Variable & n & p value \\
\hline Ferritin with $\mathrm{Hb}<10$ & 40 & \multirow{2}{*}{0,346} \\
\hline Ferritin with $\mathrm{Hb}>10$ & 5 & \\
\cline { 1 - 2 } Total & 45 & \\
\hline
\end{tabular}

Table 8. The Relationship Between Parathyroid Hormone and Hemoglobin Levels

\begin{tabular}{|l|l|l|}
\hline & n & p value \\
\hline PTH with $\mathrm{Hb}<10 \mathrm{~g} / \mathrm{dl}$ & 41 & \multirow{2}{*}{0.001} \\
\hline PTH with $\mathrm{Hb}>10 \mathrm{~g} / \mathrm{dl}$ & 4 & \\
\hline Total & 45 & \\
\hline
\end{tabular}

*Mann-Whitney U test

Table 9. The Relationship Between Parathyroid Hormone and Hematocrit Levels

\begin{tabular}{|l|l|l|}
\hline & n & p value \\
\cline { 1 - 2 } PTH with $\mathrm{Ht}<30 \%$ & 39 & \multirow{2}{*}{0.039} \\
\hline PTH with $\mathrm{Ht}>30 \%$ & 6 & \\
\hline Total & 45 & \\
\hline
\end{tabular}

*Mann-Whitney U test

\section{DISCUSSION}

According to the Kidney Disease Outcomes Quality Initiatives (KDOQI) and the 2013 Kidney Disease Improving Global 
Outcomes (KDIGO) guidelines, $\mathrm{CKD}$ is determined by structural damage or decreased kidney function for three months or more, regardless of the cause. Secondary hyperparathyroidism is a dangerous disease that develops early in the course of CKD and increases in severity as the glomerular filtration rate worsens. The normal level of iPTH in a healthy population is about 32 $\mathrm{pg} / \mathrm{ml}$. KDOQI recommends serum iPTH levels of $35-70 \mathrm{pg} / \mathrm{ml}$ for stage $3 \mathrm{CKD}, 70$ $110 \mathrm{pg} / \mathrm{ml}$ for stage 4 and $150-300 \mathrm{pg} / \mathrm{ml}$ for stage 5 and dialysis. Secondary hyperparathyroidism as well as anemia is a common complication of CKD. [6]

In this study, there was a statistically significant relationship between parathyroid hormone level and calcium phosphate level in CKD patients with regular hemodialysis ( $\mathrm{p}$ value $=0.043$ ). Parathyroid hormone, calcitonin, and vitamin D controls calcium and phosphate metabolism. These hormones regulate plasma calcium and maintain plasma phosphate. [7] Phosphate is regulated directly by vitamin $\mathrm{D}$ and indirectly by feedback from plasma calcium and parathyroid hormone. Decreased plasma phosphate concentration increases phosphate levels back to normal. First, because of the inverse relationship between plasma phosphate and calcium concentrations, which directly suppresses parathyroid hormone secretion. The decrease in parathyroid hormone causes phosphate reabsorption in the kidneys to increase, so that the plasma phosphate concentration returns to normal. Decreased plasma phosphate also increases vitamin D activation, which in turn promotes intestinal absorption of phosphate. This helps to overcome hyperphosphatemia. [8,9]

Parathyroid hormone stimulates calcium and promotes the elimination of phosphate by the kidneys during urine formation. Under the influence of parathyroid hormone, the kidneys will increase the reabsorption of filtered calcium so that less calcium passes into the urine. This effect increases plasma calcium levels and decreases urinary calcium excretion. In contrast, parathyroid hormone decreases reabsorption of phosphate so that urinary phosphate excretion increases. As a result, parathyroid hormone decreases plasma phosphate levels along with its effect on increasing calcium concentrations. Due to the solubility characteristics of the $\mathrm{Ca} 3(\mathrm{PO} 4) 2$ salt, the product of the plasma calcium and phosphate concentrations is balanced. [7]

This study also showed that there was a statistically significant relationship between parathyroid hormone level and hemoglobin level in CKD patients with regular hemodialysis $(\mathrm{p}$ value $=0.001)$. The results of this study are in line with a study by Chutia et al. and Memon et al. [10,4] Previous studies in KEEP have shown a greater prevalence of anemia among diabetic patients with CKD and in the early stages. [11] Erythropoietin levels have been shown to be lower in diabetics than among non-diabetics before significant development of CKD, suggesting the influence of diabetes on the production of this hormone. [12] Thus, another factor that may also contribute to anemia in CKD is diabetes. Meanwhile, in this study, patients with diabetes mellitus were not used as one of the inclusion or exclusion criteria. [13] The cause of low $\mathrm{Hb}$ levels or anemia is caused by the increase bone marrow fibrosis in parathyroid conditions, resulting in a decrease in erythropoietin and an increase in resistance to EPO. Erythropoietin cells express calcitriol receptors, which induce the proliferation and maturation of erythroid progenitor cells. Therefore, calcitriol deficiency can also impair erythropoiesis. $[10,14]$

This study found a significant relationship between parathyroid hormone and hematocrit as ( $p$ value $=0.039$ ). This is consistent with a previous study conducted by Adhikary et al. in which they reported a negative correlation between parathyroid hormone levels and hematocrit with a Pearson correlation $r=-0.33$. [6] Excessive PTH levels in the blood in patients with renal failure can occur through several 
mechanisms. Parathyroid hormone is responsible for hemolysis and plays a role in shortening the survival of erythrocytes. [15]

\section{CONCLUSION}

Parathyroid hormone has a statistically significant relationship with haemoglobin and haematocrit levels in CKD patients with regular hemodialysis.

\section{Acknowledgement: None}

\section{Conflict of Interest: None}

\section{Source of Funding: None}

\section{Ethical Approval: Approved}

\section{REFERENCES}

1. Suwitra, K., 2014. Penyakit Ginjal Kronik, dalam Setiati, S., Alwi, I., Sudoyo, A.W., Simadibrata, M., Setiyohadi, B. Syam, A.F, eds. Buku Ajar Ilmu Penyakit Dalam II. 6th ed. Pusat Penerbitan Ilmu Penyakit Dalam. Jakarta. Hal.1285-1288

2. Kementerian Kesehatan RI, 2017. Situasi Penyakit Ginjal Kronis. Pusat Data dan Informasi Kementerian Kesehatan RI.

3. Yuen, N., 2016. Hyperparathyroidism of Renal Disease. The Permanente Journal, 20(3), Hal.15-127.

4. Memon, I., Norris, K., Bomback, A., Peralta, C., Li, S., Chen, S., McCullough, P., Whaley-Connell, A., Jurkovitz, C., Tamura, M. dan Saab, G., 2013. The Association between Parathyroid Hormone Levels and Hemoglobin in Diabetic and Nondiabetic Participants in the National Kidney Foundation's Kidney Early Evaluation Program. Cardiorenal Medicine, 3(2), Hal.120-127.

5. Tanaka, M., Komaba, H. dan Fukagawa, M., 2018. Emerging Association Between Parathyroid Hormone and Anemia in Hemodialysis Patients. Therapeutic Apheresis and Dialysis, 22(3).

6. Adhikary, L., Pokhrel, A., Yadava, S., Khadka, D. dan Thakur, R., 2017. Relation between Serum Intact Parathyroid Hormone Level and
Hematocrit in Chronic Kidney Disease Patients. Kathmandu University Medical Journal, 13(3), Hal.220-223.

7. Guyton CA, dan Hall JE. 2007. Textbook of Medical Physiology: Pembentukan Urin oleh Ginjal 11th ed. EGC. Jakarta. Hal. 331-333.

8. Blaine, J., Chonchol, M. dan Levi, M., 2014. Renal Control of Calcium, Phosphate, and Magnesium Homeostasis. Clinical Journal of the American Society of Nephrology, 10(7), Hal.1257-1272.

9. Isakova, T., Wahl, P., Vargas, G., Gutiérrez, O., Scialla, J., Xie, H., Appleby, D., Nessel, L., Bellovich, K., Chen, J., Hamm, L., Gadegbeku, C., Horwitz, E., Townsend, R., Anderson, C., Lash, J., Hsu, C., Leonard, M. dan Wolf, M., 2011. Fibroblast growth factor 23 is elevated before parathyroid hormone and phosphate in chronic kidney disease. Kidney International, 79(12), Hal.13701378.

10. Chutia, H., Ruram, A., Bhattacharyya, H., Boruah, P. dan Nath, C., 2013. Association of Secondary Hyperparathyroidism with Hemoglobin Level in Patients with Chronic Kidney Disease. Journal of Laboratory Physicians, 5(01), Hal.51-54.

11. El-Achkar, T., Ohmit, S., Mccullough, P., Crook, E., Brown, W., Grimm, R., Bakris, G., Keane, W. dan Flack, J., 2005. Higher prevalence of anemia with diabetes mellitus in moderate kidney insufficiency: The Kidney Early Evaluation Program. Kidney International, 67(4), Hal.14831488.

12. Bosman, D., Winkler, A., Marsden, J., Macdougall, I. dan Watkins, P., 2001. Anemia With Erythropoietin Deficiency Occurs Early in Diabetic Nephropathy. Diabetes Care, 24(3), Hal.495-499.

13. Winkler, A., Marsden, J., Chaudhuri, K., Hambley, H. dan Watkins, P., 1999. Erythropoietin depletion and anaemia in diabetes mellitus. Diabetic Medicine, 16(10), Hal.813-819.

14. Russo, D., Morrone, L., Di Iorio, B., Andreucci, M., De Gregorio, M., Errichiello, C., Russo, L. dan Locatelli, F., 2014. Parathyroid hormone may be an 
Hendri Wahyudi Pinem et.al. The association between parathyroid hormone (PTH) level and hemoglobin and hematocrit level in chronic kidney disease (CKD) patients with regular hemodialysis.

early predictor of low serum hemoglobin concentration in patients with not advanced stages of chronic kidney disease. Journal of Nephrology, 28(6), Hal.701-708

15. Ali, T., Genina, A. dan Abo-Salem, O., 2014. The determinants of hepcidin level in chronic kidney disease and hemodialysis Saudi patients. Beni-Suef University Journal of Basic and Applied Sciences, 3(2), Hal.133-139.
How to cite this article: Pinem HW, Nasution AT, Nasution BR. The association between parathyroid hormone (PTH) level and hemoglobin and hematocrit level in chronic kidney disease (CKD) patients with regular hemodialysis. International Journal of Research and Review. 2021; 8(10): 412-417. DOI: https://doi.org/10.52403/ijrr.20211055 